\title{
Environmental assessment of residues generated after consecutive acid-base pretreatment of sugarcane bagasse by advanced oxidative process
}

Ivy dos Santos Oliveira ${ }^{1}$, Anuj K Chandel ${ }^{1 *}$, Messias Borges Silva ${ }^{2}$ and Silvio Silvério da Silva ${ }^{1 *}$

\begin{abstract}
Background: Biofuels produced from sugarcane bagasse (SB) have shown promising results as a suitable alternative of gasoline. Biofuels provide unique, strategic, environmental and socio-economic benefits. However, production of biofuels from SB has negative impact on environment due to the use of harsh chemicals during pretreatment. Consecutive sulfuric acid-sodium hydroxide pretreatment of SB is an effective process which eventually ameliorates the accessibility of cellulase towards cellulose for the sugars production. Alkaline hydrolysate of SB is black liquor containing high amount of dissolved lignin.

Results: This work evaluates the environmental impact of residues generated during the consecutive acid-base pretreatment of SB. Advanced oxidative process (AOP) was used based on photo-Fenton reaction mechanism (Fenton Reagent/UV). Experiments were performed in batch mode following factorial design $L_{9}$ (Taguchi orthogonal array design of experiments), considering the three operation variables: temperature $\left({ }^{\circ} \mathrm{C}\right)$, $\mathrm{pH}$, Fenton Reagent $\left(\mathrm{Fe}^{2+} / \mathrm{H}_{2} \mathrm{O}_{2}\right)+$ ultraviolet. Reduction of total phenolics (TP) and total organic carbon (TOC) were responsive variables. Among the tested conditions, experiment 7 (temperature, $35^{\circ} \mathrm{C} ; \mathrm{pH}, 2.5$; Fenton reagent, $144 \mathrm{ml} \mathrm{H} \mathrm{O}_{2}+153 \mathrm{ml} \mathrm{Fe}{ }^{2+}$; $\mathrm{UV}, 16 \mathrm{~W}$ ) revealed the maximum reduction in TP (98.65\%) and TOC (95.73\%). Parameters such as chemical oxygen demand (COD), biochemical oxygen demand (BOD), BOD/COD ratio, color intensity and turbidity also showed a significant change in AOP mediated lignin solution than the native alkaline hydrolysate.
\end{abstract}

Conclusion: AOP based on Fenton Reagent/UV reaction mechanism showed efficient removal of TP and TOC from sugarcane bagasse alkaline hydrolysate (lignin solution). To the best of our knowledge, this is the first report on statistical optimization of the removal of TP and TOC from sugarcane bagasse alkaline hydrolysate employing Fenton reagent mediated AOP process.

Keywords: Sugarcane bagasse, Environment assessment, Advance oxidative process, Photo-Fenton reaction, Total phenolics, Total organic carbon, Taguchi experimental design

\section{Background}

In the last few decades, studies on viable process for second generation ethanol production from lignocellulosic biomass have gained significant momentum worldwide. Deployment of cellulosic ethanol as an alternative of gasoline may provide unique environmental, economic and strategic benefits over to fossil fuels [1,2]. However,

\footnotetext{
* Correspondence: anuj.kumar.chandel@gmail.com; silvio@debiq.eel.usp.br 'Department of Biotechnology, Engineering School of Lorena, University of São Paulo, Estrada Municipal do Campinho, P.O. Box, Lorena/SP 116 12.602.810, Brazil
} Full list of author information is available at the end of the article concerns like environmental pollution and cost economics of ethanol production technologies are required indepth analysis for the establishment of biorefineries [3].

Sugarcane bagasse (SB) is the preferred choice of raw material for ethanol production in countries like Brazil, India and China where it is generated in plentiful amount every year $[4,5]$. SB like any other lignocellulosic material is a complex polymer which is consisted of three major constituents such as cellulose, hemicellulose and lignin. In order to utilize carbohydrate fraction of SB for ethanol production via microbial fermentation, it 
is necessary to use appropriate pretreatment method for lignin removal. Recently, consecutive acid-base pretreatment process has been found successful for the efficient removal of hemicellulose and lignin leaving cellulose for the cellulolytic enzymes action for its conversion into glucose [6,7].

During the dilute acid pretreatment of SB, hemicellulose is converted into various sugars primarily xylose and some other compounds such as furfurals, phenolics, acids and metals. This acid pretreated SB so called cellulignin when further exposed to dilute sodium hydroxide based pretreatment, considerable fraction of lignin is removed [8]. Alkalimediated pretreatment methods degrade the lignin and release phenolic compounds, aromatic alcohols and aldehydes which strongly inhibit the microbial metabolism [9-11]. Compounds derived from hemicellulose and lignin during pretreatment, if discarded in open environment, heavily pollutes the land and water. Furfurals, acids, and phenolic compounds (p-hydroxybenzoic acid, m-hydroxybenzoic acid, vanillic acid, syringic acid, p-hydroxybenzaldehyde, vanillin, cinnamic acid, syringaldehyde and others) [12,13] contribute a huge environmental damage due to high toxic content, bioaccumulation in different food chains even at low concentrations [14].

An efficient treatment method is required to overcome the contamination of phenolic compounds, furans and weak acids. In this line, several methods have been investigated such as adsorption on activated carbon, photo-catalysis using $\mathrm{TiO}_{2}$, activated carbon post-treatment, anaerobic treatment; autohydrolysis and organosolv process and several types of advanced oxidation processes (Fenton, electroFenton, sono-electro-Fenton and photo-electro-Fenton) [15-20]. Amongst them, advanced oxidative process (AOP) has shown promising results for the reduction of total phenolics and organic matter from various waste liquors. AOP are defined as potential processes that are capable of producing hydroxyl radicals $(\cdot \mathrm{OH})$, highly oxidative species, in high amounts for mineralizing organic materials to carbon dioxide, water and inorganic ions. Majority of AOP processes are performed at lower temperatures which use energy to produce highly reactive intermediaries with high oxidation or reduction potential. The hydroxyl radicals may be obtained from powerful oxidants, such as $\mathrm{H}_{2} \mathrm{O}_{2}$ and $\mathrm{O}_{3}$, combined with irradiation. These processes have shown a great advantage to degrade the pollutants [21-25].

Advancing the AOP process, Fenton reagent has been shown to be very efficient for oxidation of organic compounds which are toxic and non-biodegradable [26]. The Fenton reaction is defined as a catalytic generation of hydroxyl radicals from a chain reaction between ferrous ion $\left(\mathrm{Fe}^{2+}\right)$ and hydrogen peroxide $\left(\mathrm{H}_{2} \mathrm{O}_{2}\right)$ in an acid medium. $\mathrm{H}_{2} \mathrm{O}_{2}$ is a powerful oxidative agent, when it is catalyzed by ferrous sulfate, it produces the free radical $\bullet \mathrm{OH}$ (hydroxyl) which has $60 \%$ higher oxidation power than the peroxide.
In addition, this radical has the ability of degrading the organic material of effluents in a more efficient way [27]. With a high oxidative potential, these hydroxyl radicals are the responsible for oxidation of organic compounds present in waste waters. The radical $\mathrm{Fe}^{2+}$ is the reaction catalyst. Nowadays, this process is used for treating a wide variety of toxic organic compounds that do not respond to biological treatments, or even in rehabilitation of contaminated land $[28,29]$. This study aims to evaluate the environmental impact of residues generated during the consecutive acid-base pretreatment of sugarcane bagasse. Advanced oxidative process (AOP) was used based on photo-Fenton reaction mechanism (Fenton Reagent/UV) for the elimination of total phenolics in lignin solution in conjunction with reduction in BOD/COD ratio.

\section{Results and discussion}

\section{Characteristics of lignin residue}

The lignin residue was characterized based on the physicochemical parameters, such as $\mathrm{pH}$, color, TOC, COD, BOD, turbidity, COD/BOD ratio and TP amount. Table 1 shows the physical and chemical characteristics of alkaline hydrolysates (native lignin solution) [30]. The COD/BOD ratio in native lignin solution was 0.03 lower than the standard value (0.2) revealing that the substances present in lignin solution residues are resistant to biological oxidation [31]. The color and turbidity analysis demonstrate that the effluent has intense color and turbidity. The presence of phenolic compounds in the alkaline hydrolysates shows the important characteristic of lignin solutions. During the photo-Fenton reaction of lignin solution, extensive amount of foam was generated. Excessive foam causes interference during the photo-Fenton reaction. Therefore, it is necessary to strictly control the foam generation. During the photo-Fenton reaction, all amount of hydrogen peroxide was consumed.

\section{Statistical analysis of $L_{9}$ Taguchi experimental design Changes in total oxygen concentration (TOC)}

Table 2 demonstrates the percentage change in the TOC of lignin solution after photo-Fenton reactions in each

Table 1 Physical and chemical characteristics of residual lignin

\begin{tabular}{lcc}
\hline Parameters & Characteristics & Standards $^{*}$ \\
\hline True color (PtCo) & 3621.33 & Absent \\
Turbidity (NTU) & 50.8 & Absent \\
$\mathrm{pH}$ & $7-8$ & $5-9$ \\
$\mathrm{COD}\left(\mathrm{mg} / \mathrm{L} \mathrm{O}_{2}\right)$ & 5870.25 & 8 \\
$\mathrm{BOD}\left(\mathrm{mg} / \mathrm{L} \mathrm{O}_{2}\right)$ & 169 & 60 \\
$\mathrm{COD} / \mathrm{BOD}$ & 0.03 & - \\
TOC $(\mathrm{mg} / \mathrm{L})$ & 2053.0 & - \\
Total Phenol $(\mathrm{mg} / \mathrm{L})$ & 10.64 & 0.5 \\
\hline
\end{tabular}

*Effluents standards in hybrid bodies - Article 18 [31] and [32] respectively. (-) Unspecified. 
Table 2 Profile of percentage reduction of TOC values in all 9 experiments (photo-Fenton reaction) performed as per $L_{9}$ Taguchi matrix

\begin{tabular}{|c|c|c|c|c|}
\hline \multirow[t]{2}{*}{ Exp. } & \multicolumn{2}{|c|}{ TOC range (\%) } & \multirow{2}{*}{$\begin{array}{c}\text { Average } \\
\text { (\%) }\end{array}$} & \multirow{2}{*}{$\begin{array}{l}\mathrm{S}_{\mathrm{i}}{ }^{2 *} \\
(\%)\end{array}$} \\
\hline & $1^{\circ}$ Data set & $2^{\circ}$ Data set & & \\
\hline 1 & 91.92 & 93.68 & 92.80 & 1.55 \\
\hline 2 & 90.21 & 92.90 & 91.56 & 3.62 \\
\hline 3 & 91.96 & 93.49 & 92.73 & 1.17 \\
\hline 4 & 90.49 & 90.40 & 90.45 & 0.00 \\
\hline 5 & 93.97 & 94.60 & 94.28 & 0.20 \\
\hline 6 & 92.30 & 92.92 & 92.61 & 0.19 \\
\hline 7 & 95.18 & 96.28 & 95.73 & 0.60 \\
\hline 8 & 91.82 & 93.58 & 92.70 & 1.55 \\
\hline 9 & 92.08 & 94.70 & 93.39 & 3.43 \\
\hline
\end{tabular}

experiment carried out as per the $\mathrm{L}_{9}$ orthogonal design of experiments. As can be observed from Table 2, experiment 2 and 9 only have the higher values of standard variation $\left(\mathrm{S}_{\mathrm{i}}{ }^{2}\right)$ showing 3.62 and 3.43 respectively. Different modifications in AOP have shown the satisfactory results for the treatment of the lignin solution. For example, Ninomiya et al. [33] recently studied the sonocatalytic-Fenton reaction for the degradation of lignin. Sonocatalytic-Fenton reaction showed synergistically enhanced $\cdot \mathrm{OH}$ radical generation. The $\bullet \mathrm{OH}$ radical generation was applied to lignin degradation and biomass pretreatment. Lignin degradation ratio by sono-catalytic-Fenton reaction was $60.0 \%$ at $180 \mathrm{~min}$. Ma et al. [32] studied photo-catalytic degradation of lignin with the use of catalysts $\mathrm{TiO}_{2}$ and $\mathrm{Pt} / \mathrm{TiO}_{2}$. The results showed that application of UV irradiation alone has almost no effect on the reduction of dissolved organic carbon (DOC). However, the addition of $\mathrm{TiO}_{2}$ and $\mathrm{Pt} / \mathrm{TiO}_{2}$ reduced the original DOC $(251 \mathrm{mg} / \mathrm{L})$ by more than $40 \%$ within 30 minutes of treatment. Makhotkina et al. [34] also used Fenton and $\mathrm{H}_{2} \mathrm{O}_{2}$ photo-assisted reactions for and observed 85\% lignin oxidation, at $0.1 \mathrm{M}$ concentration under UV-radiation at $\mathrm{pH} 8.3$.

Table 3 presents the average percentage change in TOC in all nine experiments carried out according to Taguchi $\mathrm{L}_{9}$ orthogonal design. Experimental run 7 (temperature $35^{\circ} \mathrm{C} ; \mathrm{pH} 2.5$; Fenton concentration 144 $\mathrm{mL} \mathrm{H}_{2} \mathrm{O}_{2}+153 \mathrm{~mL} \mathrm{Fe}{ }^{2+}$; UV range $16 \mathrm{~W}$ ) showed the 95.73\% TOC reduction. On the other hand, experimental run 4 (temperature $30^{\circ} \mathrm{C}$; $\mathrm{pH} 2.5$; Fenton concentration $120 \mathrm{~mL} \mathrm{H}_{2} \mathrm{O}_{2}+120 \mathrm{~mL} \mathrm{Fe}{ }^{2+}$; $\mathrm{UV}$ range $28 \mathrm{~W}$ ) showed the minimum percentage change in TOC value (90.45\%). This positive effect of UV radiation on degradation reaction was attributed to the reduction of $\mathrm{Fe}^{3+}$ to $\mathrm{Fe}^{2+}$ which in turn reacts with $\mathrm{H}_{2} \mathrm{O}_{2}$ allowing for the continued Fenton reaction. The absorbance of ferric ions may extend into the visible region, depending on the $\mathrm{pH}$
Table 3 Average value of TOC percentage reduction in lignin solution using photo-Fenton after in all 9 experiments designed as per $L_{\mathbf{g}}$ Taguchi matrix

\begin{tabular}{cccccc}
\hline Exp. & $\begin{array}{c}\text { Temperature } \\
\left({ }^{\circ} \mathrm{C}\right)\end{array}$ & $\mathbf{p H}$ & $\begin{array}{c}\text { Fenton } \\
\left(\mathrm{mg} \mathrm{L}^{-1}\right)\end{array}$ & $\begin{array}{c}\text { UV } \\
(\mathbf{W})\end{array}$ & $\begin{array}{c}\text { TOC } \\
\text { average } \\
(\%)\end{array}$ \\
\hline 1 & 1 & 1 & 1 & 1 & 92.80 \\
2 & 1 & 2 & 2 & 2 & 91.56 \\
3 & 1 & 3 & 3 & 3 & 92.73 \\
4 & 2 & 1 & 2 & 3 & 90.45 \\
5 & 2 & 2 & 3 & 1 & 94.28 \\
6 & 2 & 3 & 1 & 2 & 92.61 \\
7 & 3 & 1 & 3 & 2 & 95.73 \\
8 & 3 & 2 & 1 & 3 & 92.70 \\
9 & 3 & 3 & 2 & 1 & 93.39 \\
\hline
\end{tabular}

because the $\mathrm{pH}$ influences the formation of hydroxylated species, which have higher absorption in the visible [35]. It is interesting to note that $\mathrm{pH}$ around 3.0 proved to be more effective for the reduction of organic matter present in the residue using photo-Fenton process. Several studies have confirmed this behavior [35-38]. Higher concentration of the Fenton's reagent was more effective for the reduction of organic matter due to the generation of hydroxyl radicals in greater amount. The extensive degradation of lignin was possibly due to the oxidative properties of the Fenton's reagent [39].

The effect of individual parameters on TOC reduction during photo-Fenton reaction has been shown in Figure 1. It is clear from the Figure 1 that $\mathrm{pH}$ had no significant effect on the TOC percentage reduction. The Fenton reagent ( $144 \mathrm{~mL}$ of $\mathrm{H}_{2} \mathrm{O}_{2}+153 \mathrm{~mL}$ of $\mathrm{Fe}^{2+}$ ) and temperature showed high impact in the process. It can be observed that the UV irradiation presence $(16 \mathrm{~W})$ or absence has a better contribution in the percentage TOC reduction. One of the possible explanations for this fact is the intense color of the residue, which interferences UV irradiation process. It can also be observed that the higher temperature $\left(35^{\circ} \mathrm{C}\right)$ has a great significance (Table 3 ).

High Fenton reagent level majorly influenced the percentage TOC reduction. Table 4 presents the ANOVA of involved factors in both lignin residue treatment and photo-Fenton process, according to $\mathrm{L}_{9}$ Taguchi experimental matrix. ANOVA presented in Table 4 clearly demonstrates that the Fenton reagent concentration was the most significant effect factor in the TOC percentage reduction, with $\mathrm{F}$ equals 6.8 and $\mathrm{p}$-value equals 0.0156 , followed by temperature $(\mathrm{F}=3.5)$ and UV irradiation $(\mathrm{F}=3.1)$ as already shown in Figure 2. The effect of $\mathrm{pH}$ was not found significant in TOC reduction $(F=0.02)$. The effect of Fenton concentration in percentage TOC reduction was more pronounced (almost twice) than temperature and UV irradiation variables and six times 


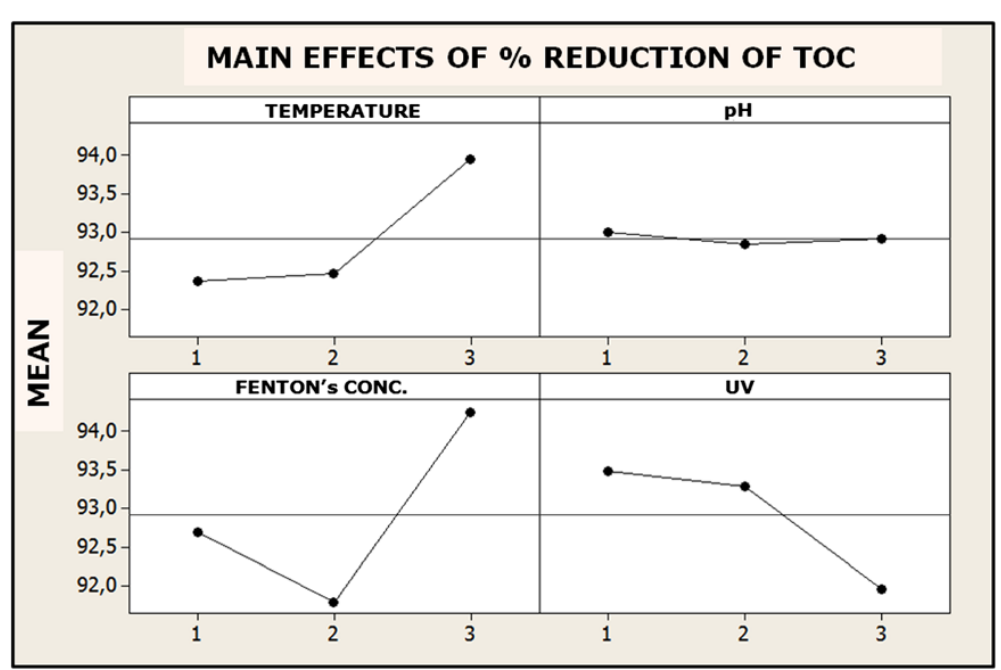

Figure 1 Main effects of different process variables (temperature, $\mathrm{pH}, \mathrm{H}_{2} \mathrm{O}_{2}$ concentration and $\mathrm{UV}$ radiation) on TOC percentage reduction in lignin solution treated by photo-Fenton process.

more than $\mathrm{pH}$ variable. Figure 2 reveals the variability of the process parameters by average answers graph according to the signal-to-noise ratio $(\mathrm{S} / \mathrm{R})$. The best pool of conditions (temperature $35^{\circ} \mathrm{C}, 144 \mathrm{~mL}$ of $\mathrm{H}_{2} \mathrm{O}_{2}$ and $153 \mathrm{~mL}$ of $\mathrm{Fe}^{2+}$ ) was found for percentage TOC reduction in lignin solution after AOP. Figures 1 and 2 clearly reveal the influence of UV irradiation on the percentage reduction of TOC at lowest and highest value. At the highest level of UV irradiation, a remarkable decrease in TOC was observed.

\section{Changes in total phenols concentration}

Table 5 shows the average reduction percentage of phenol compounds obtained from double process of experimental conditions in lignin residue treatment, according to $\mathrm{L}_{9}$ orthogonal design. The maximum reduction in TP level from lignin solution was $98.65 \%$ in experiment 7 (Table 5). Figure 3 shows the main effect of four process variables (temperature, $\mathrm{pH}$, Fenton reagent concentration and UV radiation) on percentage reduction of TP concentration in lignin solution.

The experiments 6 and 8 have shown similar phenolics degradation behavior, with around $97 \%$ of average

Table 4 Analysis of variance (ANOVA) for the average values of TOC percentage reduction in the photo-Fenton process based experiments as per $L_{9}$ orthogonal design of experiments

\begin{tabular}{lccccc}
\hline Factors & $\begin{array}{c}\text { Sum of } \\
\text { square }\end{array}$ & $\begin{array}{c}\text { Degree of } \\
\text { freedom }\end{array}$ & $\begin{array}{c}\text { Average sum } \\
\text { of square }\end{array}$ & F & p-value \\
\hline Temperature & 9.50 & 2 & 4.70 & 3.50 & 0.0763 \\
$\mathrm{pH}$ & 0.10 & 2 & 0.03 & 0.02 & 0.9766 \\
Fenton Concentration & 18.60 & 2 & 9.30 & 6.80 & 0.0156 \\
Residual & 8.40 & 2 & 4.20 & 3.10 & 0.0962 \\
UV & 12.30 & 9 & 1.40 & - & - \\
\hline
\end{tabular}

reduction of TP. The experimental conditions which were studied for both experiments demonstrated the temperature range was $30-35^{\circ} \mathrm{C}, \mathrm{pH}$ between $3,0-3,5$, low level of Fenton reagent for both experiments $(96 \mathrm{~mL}$ of $\mathrm{H}_{2} \mathrm{O}_{2}$ and $87 \mathrm{~mL}$ of $\mathrm{Fe}^{2}$ ) and irradiation presence in UV $(16-28 \mathrm{~W})$ were not so effective as compared with the experiment 7. Experiment 7 (temperature $35^{\circ} \mathrm{C}, \mathrm{pH}$ 2.5, Fenton reagent $\mathrm{H}_{2} \mathrm{O}_{2} 144 \mathrm{ml}+\mathrm{Fe}^{2+} 153 \mathrm{~mL}$ and UV irradiation $16 \mathrm{~W}$, proved maximum reduction in TP (98.65\%). This combination has shown the best degradation result in the phenol compounds from lignin residue. Table 6 presents the percentage range, the average percentage and the variance $\left(\mathrm{S}_{\mathrm{i}}{ }^{2}\right)$ in TP concentration in lignin solution after AOP in all 9 experiments performed according to $\mathrm{L}_{9}$ matrix. It is clear from Table 6 that experiment 7 and 9 showed the higher values of standard deviation, 2.06 and 2.04 respectively. Table 7 shows the ANOVA of each process variables involved in lignin residue treatment using photo-Fenton process, according to $\mathrm{L}_{9}$ Taguchi experimental matrix.

It can be observed that all the factors were significant for the studied process parameters in $\mathrm{L}_{9}$ Taguchi matrix. The most significant factor was UV irradiation with $\mathrm{F}$ value of 404.00 followed by Fenton reagent concentration $(F=218.80)$ and temperature $(F=203.1)$. It can also be observed from the Table 6 , that the experiments where UV irradiation were used (experiments 2, 3, 4, 6, 7 and 8) showed an average 95\% of removal of phenolic compounds from the lignin solution. Fenton reagent concentration was the second most influence factor (Table 7). Fenton reagent at the concentration $\left(96 \mathrm{~mL}\right.$ of $\mathrm{H}_{2} \mathrm{O}_{2}$ and $87 \mathrm{~mL}$ of $\mathrm{Fe}^{2+}$ ) with $\mathrm{UV}$ presence and $\mathrm{pH}$ range (3.0-3.5) has shown about $97 \%$ removal of total phenolics from lignin solution. Fenton reagent concentration at an 


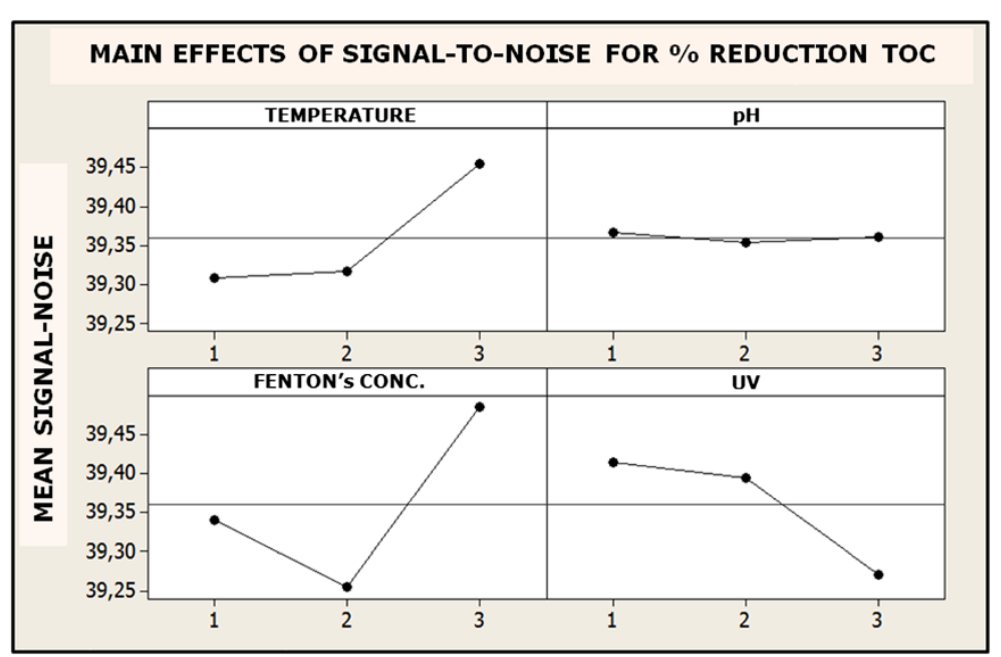

Figure 2 Effect of independent variable on the percentage reduction of TOC in terms of S/N ratio (the larger is the best) by photo-Fenton process according to $L_{9}$ Taguchi matrix.

intermediate level $\left(120 \mathrm{~mL}\right.$ of $\mathrm{H}_{2} \mathrm{O}_{2}$ and $120 \mathrm{~mL}$ of $\mathrm{Fe}^{2+}$ ) in the UV presence, showed average $89 \%$ of removal of phenolic compounds. In experiment 9, where the Fenton reagent were used at an intermediate level, the average of phenolic compounds removal was about $67 \%$ probably due to the UV absence in the reaction medium. UV promotes the larger production of $\bullet \mathrm{OH}$ radicals which facilitates the large organic material degradation. Figure 4 shows the influence of process variables showing the $\mathrm{S} / \mathrm{N}$ ratio. Clearly, the greater total phenol reduction percentage (larger signal) is the better. It is clear from the figure that temperature at level $2\left(30^{\circ} \mathrm{C}\right)$ was more effective than level $1\left(25^{\circ} \mathrm{C}\right)$ and level $3\left(35^{\circ} \mathrm{C}\right)$. The effect of $\mathrm{pH}$ on percentage TOC reduction was not significant. Concentration of Fenton at level 3 showed remarkable percentage reduction in total phenolics concentration. Similarly, UV ranges at level $3(28 \mathrm{~W})$ showed pronounced effect on total

Table 5 Average value of total phenols percentage reduction in specific factors and levels to $L_{9}$ Taguchi experiments after lignin residue treatment using photo-Fenton process

\begin{tabular}{cccccc}
\hline Exp. & Temperature $\left({ }^{\circ} \mathrm{C}\right)$ & $\mathbf{p H}$ & $\begin{array}{c}\text { Fenton } \\
\left(\mathrm{mg} \mathrm{L}^{-1}\right)\end{array}$ & $\mathbf{U V}(\mathrm{W})$ & $\begin{array}{c}\text { Average of total } \\
\text { phenols (\%) }\end{array}$ \\
\hline 1 & 1 & 1 & 1 & 1 & 71.10 \\
2 & 1 & 2 & 2 & 2 & 84.78 \\
3 & 1 & 3 & 3 & 3 & 95.98 \\
4 & 2 & 1 & 2 & 3 & 94.08 \\
5 & 2 & 2 & 3 & 1 & 96.49 \\
6 & 2 & 3 & 1 & 2 & 97.02 \\
7 & 3 & 1 & 3 & 2 & 98.65 \\
8 & 3 & 2 & 1 & 3 & 97.30 \\
9 & 3 & 3 & 2 & 1 & 66.99 \\
\hline
\end{tabular}

phenolics concentration. Summarizing the effect of these parameters on total phenolics concentration according to $\mathrm{L}_{9}$ Taguchi matrix design of experiment, it can be concluded that the larger $\mathrm{S} / \mathrm{N}$ ratio (the larger is the best) had the strong influence on total phenolics percentage reduction.

\section{Materials and methods}

\section{Raw material}

Sugarcane bagasse was acquired from Santa Fé S/A Plant, Nova Europa/SP city. The sugarcane bagasse was used in this experimental as it was obtained from sugarcane processing mill. The processing unit milled the bagasse before sending to laboratory. However, it was not further milled. Thus, sugarcane bagasse was nonuniform in size. It was sun-dried prior to acid hydrolysis in order to remove the extra water. Prior to use in experiment, the moisture content of sugarcane bagasse was analyzed. The total moisture level in bagasse was $10 \%$. This humidity was taken into consideration in acid hydrolysis experiment.

\section{Dilute acid hydrolysis}

The dilute acid hydrolysis of SB was carried out in a hydrolysis reactor of capacity of $350 \mathrm{~L}$ located at the Engineering School of Lorena (EEL)-USP, Lorena, Brazil. For the hydrolysis of the $\mathrm{SB}, \mathrm{H}_{2} \mathrm{SO}_{4}$ (98\% of purity) was used as catalyst in a ratio of $100 \mathrm{mg}$ of acid/g of dry matter, during $20 \mathrm{~min}$ at $121^{\circ} \mathrm{C}$, using a ratio of $1 / 10$ between the bagasse mass and the volume of acid solution. The hydrolysate obtained was maintained at $4^{\circ} \mathrm{C}$. The recovered solid residue so called cellulignin was washed with running tap water until the neutralized $\mathrm{pH}$, sundried to remove the moisture and was subsequently used for delignification experiments. 


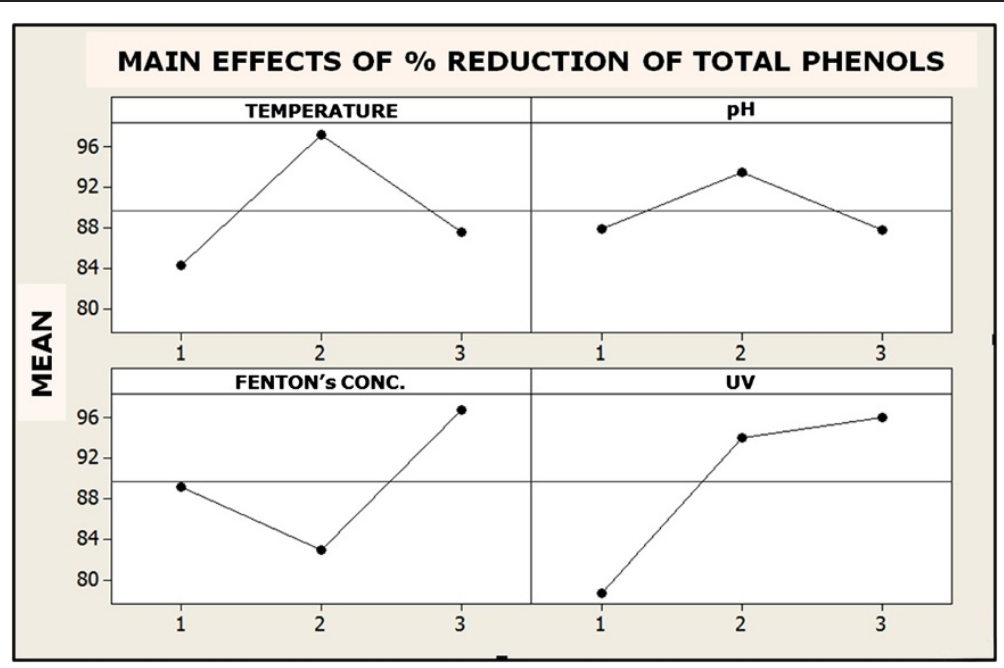

Figure 3 Main effects of independent variables (temperature, $\mathrm{pH}$, Fenton reagent concentration and UV irradiation) on total phenols percentage reduction from lignin solution by photo-Fenton process, according to $L_{9}$ Taguchi matrix design of experiment.

Dilute sodium hydroxide pretreatment of cellulignin Cellulignin recovered after dilute acid hydrolysis was submitted to alkaline hydrolysis to recover the lignin solution. For the alkaline hydrolysis, sodium hydroxide (1M) was mixed with cellulignin in the ratio of 1:10. Alkaline hydrolysis was performed in rotatory reactor of capacity $50 \mathrm{~L}$. The reaction was performed at $121^{\circ} \mathrm{C}$ for $10 \mathrm{~min}$. After cooling the reaction mixture, the liquid fraction (soluble lignin) was separated and subsequently was used for advanced oxidation process (AOP).

\section{Color determination}

Color of lignin solution after alkaline hydrolysis (native) and after AOP was determined by UV-visible spectrophotometer (Bel Photonics, Italy), by using interpolation of an analytical calibration curve as a function of

Table 6 Percentage reduction values of total phenol concentration lignin solution in all 9 experiments carried out as per $L_{9}$ Taguchi matrix

\begin{tabular}{|c|c|c|c|c|}
\hline \multirow[t]{2}{*}{ Exp. } & \multicolumn{2}{|c|}{ Total phenol range (\%) } & \multirow{2}{*}{$\begin{array}{c}\text { Average } \\
(\%)\end{array}$} & \multirow{2}{*}{$\begin{array}{l}S_{i}^{2 *} \\
(\%)\end{array}$} \\
\hline & $1^{\circ}$ Data set & $2^{\circ}$ Data set & & \\
\hline 1 & 70.60 & 71.60 & 71.10 & 0.50 \\
\hline 2 & 85.30 & 84.25 & 84.78 & 0.55 \\
\hline 3 & 96.00 & 95.95 & 95.98 & 0.00 \\
\hline 4 & 94.15 & 94.00 & 94.08 & 0.01 \\
\hline 5 & 96.17 & 96.80 & 96.49 & 0.20 \\
\hline 6 & 97.03 & 97.00 & 97.02 & 1.46 \\
\hline 7 & 97.79 & 99.50 & 98.65 & 2.06 \\
\hline 8 & 97.80 & 96.80 & 97.30 & 0.50 \\
\hline 9 & 65.98 & 68.00 & 66.99 & 2.04 \\
\hline
\end{tabular}

absorbance measurement at $400 \mathrm{~nm}$ of wavelength using platinum-cobalt standards [30].

\section{Turbidity determination}

Turbidity measurement of lignin solution after alkaline hydrolysis (native) and after AOP was determined by using a turbidity meter with a precision of $2 \%$ (Tecnopon TB 1000). For the calibration of the equipment, standards of 0.1 to 1000 Turbidity Unit of standard solution (Formazin at different dilutions) were used.

Chemical oxygen demand (COD) and biochemical oxygen demand (BOD) analysis

All analytical determinations were performed according to the Standard Methods of Examination of Water and Wastewater [40]. The COD determination is based on the oxidation of organic matter by reduction of potassium dichromate in an acidic medium containing catalyst at elevated temperature and subsequent reading absorbance at a wavelength of $620 \mathrm{~nm}$ [41].

Table 7 Analysis of variance (ANOVA) obtained from average values of total phenols percentage reduction from $L_{9}$ orthogonal design to lignin residue treatment using photo-Fenton process

\begin{tabular}{lccccc}
\hline Factors & $\begin{array}{c}\text { Square } \\
\text { sum }\end{array}$ & $\begin{array}{c}\text { Degree of } \\
\text { freedom }\end{array}$ & $\begin{array}{c}\text { Average } \\
\text { square sum }\end{array}$ & $\mathbf{F}$ & $\mathbf{p}$ \\
\hline Temperature & 542.35 & 2 & 271.2 & 203.10 & 0.0000 \\
$\mathrm{pH}$ & 127.92 & 2 & 64.0 & 47.90 & 0.0000 \\
Fenton concentration & 584.42 & 2 & 292.2 & 218.80 & 0.0000 \\
Residual & 1078.91 & 2 & 539.5 & 404.00 & 0.0000 \\
UV & 12.02 & 9 & 1.30 & - & - \\
\hline
\end{tabular}




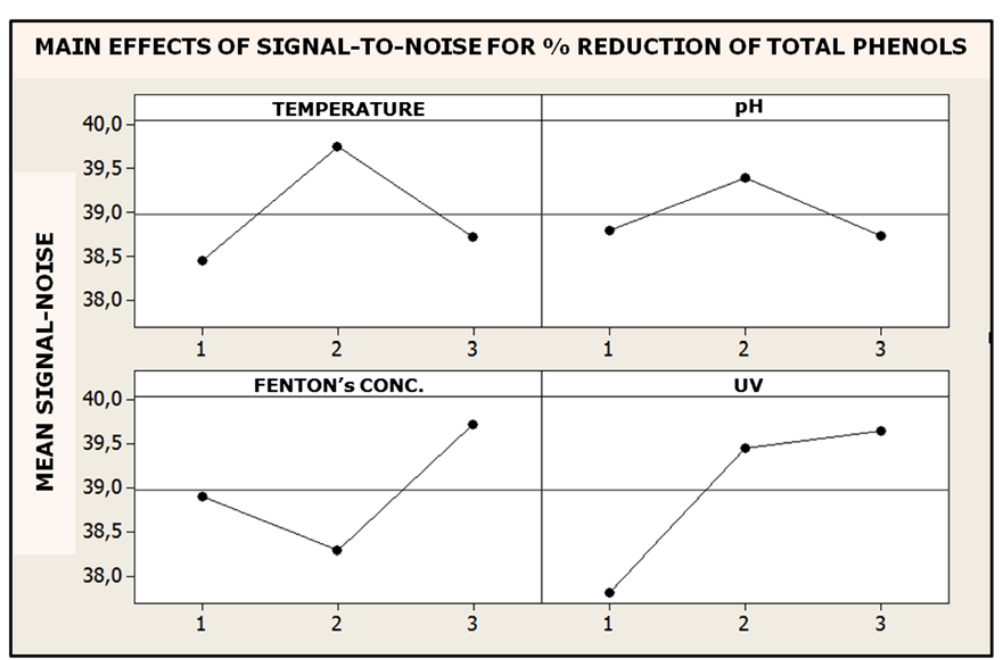

Figure 4 Main effects of process variables (temperature, $\mathrm{pH}$, Fenton reagent concentration and UV radiation) on total phenols percentage reduction from lignin solution by photo-Fenton process, according to $\mathrm{L}_{9}$ Taguchi matrix design of experiment. $\mathrm{S} / \mathrm{N}$ ratio (the larger is the best) to total phenol percentage reduction.

In this procedure, the sample was heated for $2 \mathrm{hrs}$ with potassium dichromate in a closed system. During this reaction, oxidizing organic compounds reduce with the conversion of dichromate ion into chromic ion green. The reagents used also contain mercury and silver ions. Silver is a catalyst, and mercury is used to control interference chloride. To determine the accuracy of the method, potassium bi-phthalate $(850 \mathrm{mg} / \mathrm{L})$ was used as a standard [42].

In the digestion flasks, $2.0 \mathrm{~mL}$ sample, $0.5 \mathrm{~mL}$ of digesting solution and $2.5 \mathrm{~mL}$ of the catalyst solution were mixed. The mixture was heated at $150^{\circ} \mathrm{C}$ for $2 \mathrm{~h}$. After the cooling to ambient temperature, absorbance was read at $620 \mathrm{~nm}$. The $\mathrm{O}_{2}$ concentration of the sample was obtained by interpolating the data obtained from the calibration curve performed with a standard solution of potassium bi-phthalate. Standards were prepared of standard values of COD (20-1065). The BOD test is based on the amount of oxygen needed by microorganisms to for the degradation of organic compounds. Organic compounds that were not biodegradable were considered to have BOD value as "zero" [30].

\section{Total organic carbon (TOC) determination}

TOC in lignin solution after alkaline hydrolysis (native) and after AOP was detected by TOC analyzer (TOC$\mathrm{VCPH}$, Shimadzu, Japan).

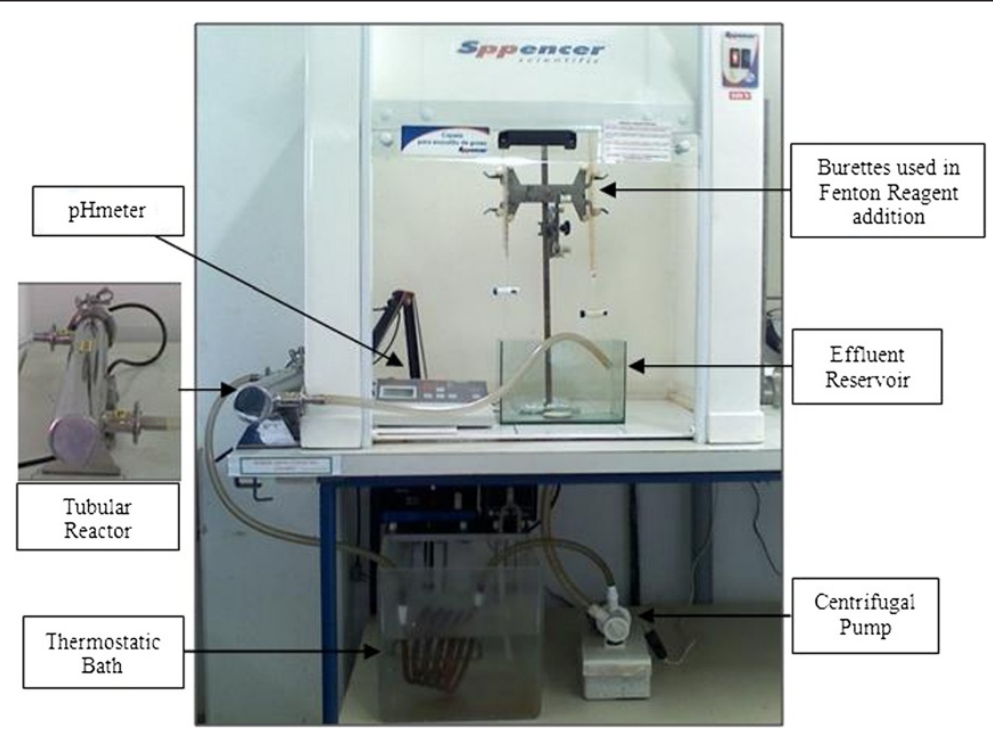

Figure 5 Lay-out of the experimental procedure to the treatment step of lignin residue using AOPs. 
Total phenolics (TP) estimation

TP amount in lignin solution (native) and after AOP was analyzed by the colorimetric method using ferricyanide and antipyrine without extraction $(0-5.0 \mathrm{mg} / \mathrm{L})$ [30].

\section{Advanced oxidative process $\left(\mathrm{Fe}^{2+} / \mathrm{H}_{2} \mathrm{O}_{2}\right.$ and UV irradiation)}

AOP of alkaline hydrolysate of sugarcane bagasse (lignin solution) was performed in a tubular photochemical reactor (GPJ-463/1, Germetec S/A, Brasil) with a volume of approximately $1 \mathrm{~L}$ at the irradiation of low pressure mercury lamp (GPH-463T5L, Germetec S/A, Brasil), emitting UV radiation at $254 \mathrm{~nm}$ with potentials of 16 and $28 \mathrm{~W}$, protected by a quartz tube. The reactor configuration as shown in Figure 5, was used for AOP using 3L of lignin solution. The photochemical treatment was carried out in a batch mode. For the Fenton reaction, the volume of the reagents $\left(\mathrm{H}_{2} \mathrm{O}_{2}, 30 \%\right.$ and $\mathrm{FeSO}_{4} .7 \mathrm{H}_{2} \mathrm{O}, 0.18$ $\mathrm{mol} / \mathrm{L}$ ) were added. $\mathrm{H}_{2} \mathrm{O}_{2}$ was added first as drops followed by the addition of $\mathrm{FeSO}_{4} \cdot 7 \mathrm{H}_{2} \mathrm{O}$ in the lignin solution. AOP was continued up to $2 \mathrm{hrs}$ and the samples were withdrawn after every $10 \mathrm{~min}$. These aliquots were previously adjusted to a $\mathrm{pH}$ between 7.0 and 8.0 for precipitation of iron salts and then subjected to analysis of COD, color, turbidity and TOC.

\section{Experimental design}

To optimize the effect of process variables $(\mathrm{pH}$, temperature, $\mathrm{H}_{2} \mathrm{O}_{2}$ and Fenton's $\mathrm{Fe}^{2+}$ concentrations and UV radiation potential), a factorial statistical design ( $\mathrm{L}_{9}$ Taguchi orthogonal array design of experiments) was performed. Percentage reduction in total phenolics concentration and TOC reduction after AOP were the responsive variables (Tables 8 and 9).

\section{Economic feasibility of the process}

Two things are needed for any technology to be suitable for use in the industry- the technical feasibility and the economic feasibility. Table 10 shows some examples of cost economic analysis of AOP process employed for the treatment of various kinds of wastes generated.

Table 8 Process variables and their ranges selected for the AOP with photo-Fenton process applied to lignin solution using $L_{g}$ Taguchi matrix

\begin{tabular}{|c|c|c|c|}
\hline Factors & Level 1 & Level 2 & Level 3 \\
\hline Temperature $\left({ }^{\circ} \mathrm{C}\right)$ & 25 & 30 & 35 \\
\hline $\mathrm{pH}$ & 2.5 & 3.0 & 3.5 \\
\hline \multirow{2}{*}{$\begin{array}{l}\text { Fenton Reagent } \\
\left(m_{\mathrm{H} 2 \mathrm{O} 2} \mathrm{~g}+\mathrm{m}_{\mathrm{Fe}+2} \mathrm{~L}^{-1}\right)\end{array}$} & $96 \mathrm{~mL} \mathrm{H} \mathrm{O}_{2}+$ & $120 \mathrm{~mL} \mathrm{H} \mathrm{O}_{2}+$ & $144 \mathrm{~mL} \mathrm{H} \mathrm{O}_{2}+$ \\
\hline & $87 \mathrm{~mL}$ sol $\mathrm{Fe}^{2+}$ & $120 \mathrm{~mL} \mathrm{Fe} e^{2+}$ & $153 \mathrm{~mL} \mathrm{Fe}{ }^{2+}$ \\
\hline Ultra-violet irradiation & None & $16 \mathrm{~W}$ & $28 \mathrm{~W}$ \\
\hline
\end{tabular}

${ }^{*}$ Both $\mathrm{H}_{2} \mathrm{O}_{2}$ and Iron II were used in solutions with concentrations of $\left[\mathrm{H}_{2} \mathrm{O}_{2}\right]$, $30 \% \mathrm{~m} / \mathrm{m}$ and $\left[\mathrm{Fe}^{2+}\right], 0.82 \mathrm{~mol} / \mathrm{L}$. These values are the proportional to the treated effluent volume of $3 \mathrm{~L}$.
Table 9 Experimental plans considering $L_{9}$ orthogonal Taguchi design divided in 3 levels (low represented by 1, intermediary represented by 2 and high represented by $3)$, to the lignin residue treatment using photo-Fenton

\begin{tabular}{ccccc}
\hline Experiment & Temperature $\left({ }^{\circ} \mathbf{C}\right)$ & $\mathbf{p H}$ & Fenton reagent & UV \\
\hline 1 & 1 & 1 & 1 & 1 \\
2 & 1 & 2 & 2 & 2 \\
3 & 1 & 3 & 3 & 3 \\
4 & 2 & 1 & 2 & 3 \\
5 & 2 & 2 & 3 & 1 \\
6 & 2 & 3 & 1 & 2 \\
7 & 3 & 1 & 3 & 2 \\
8 & 3 & 2 & 1 & 3 \\
9 & 3 & 3 & 2 & 1 \\
\hline
\end{tabular}

\section{Conclusions}

Second generation ethanol production based biorefineries generate high amount of lignin solution due to the alkali mediated delignification pretreatment step. Lignin solution is extremely of high recalcitrance with high $\mathrm{BOD} / \mathrm{COD}$ ratio of 0.25 . An ordinary biological pretreatment is not enough to degrade the phenolics amount and consequently bring down the TOC of lignin solution up to satisfactory levels. Therefore, the involvement of AOP is highly recommended to facilitate the phenolics degradation and consequently bring down the TOC levels in lignin solution, recovered from biomass pretreatment. This study clearly demonstrates that AOP mediated by photo-Fenton reaction is highly efficient for the removal of organic material in conjunction with bring down the levels of TOC from sugarcane bagasse

Table 10 Cost-economic analysis of some advanced oxidation processes used for various kinds of wastes

\begin{tabular}{|c|c|c|c|}
\hline $\begin{array}{l}\text { Type of } \\
\text { process }\end{array}$ & Type of waste & $\begin{array}{l}\text { Estimated cost for the } \\
\text { process used }\end{array}$ & Reference \\
\hline $\begin{array}{l}\mathrm{UV} / \mathrm{H}_{2} \mathrm{O}_{2} \text { and } \\
\text { UV/TiO }\end{array}$ & Synthetic water & $\begin{array}{c}\text { Electricity costs were assumed } \\
\text { fixed over the } 15 \mathrm{yr} \text { at } £ 0.09 \\
\text { per KW h and hydrogen } \\
\text { peroxide fixed at } £ 270 \mathrm{~m}^{-3}\end{array}$ & {$[43]$} \\
\hline $\begin{array}{l}\mathrm{H}_{2} \mathrm{O}_{2} / \mathrm{UV} \text { and } \\
\mathrm{Fe}^{2+} / \mathrm{H}_{2} \mathrm{O}_{2}\end{array}$ & $\begin{array}{l}\text { Polyester and } \\
\text { acetate fiber } \\
\text { dyeing effluent }\end{array}$ & $0.23\left(\$ m^{-3}\right)$ and $1.26\left(\$ m^{-3}\right)$ & {$[44]$} \\
\hline \multirow[t]{2}{*}{$\mathrm{Fe}^{2+} / \mathrm{H}_{2} \mathrm{O}_{2}$} & \multirow{2}{*}{$\begin{array}{l}\text { 4-Chlorophenol } \\
\text { and Olive oil }\end{array}$} & $\mathrm{Fe}^{2+} 0.2$ and $\mathrm{H}_{2} \mathrm{O}_{2} 10\left(\mathrm{~kg} \mathrm{~m}^{-3}\right)$ & \multirow[t]{2}{*}[45]{} \\
\hline & & $\mathrm{Fe}^{2+} 0.7$ and $\mathrm{H}_{2} \mathrm{O}_{2} 18\left(\mathrm{~kg} \mathrm{~m}^{-3}\right)$ & \\
\hline Photocatalysis & $\begin{array}{l}\text { Phenol waste } \\
\text { water }\end{array}$ & $43.36(\$ / L)$ for all the process & {$[46]$} \\
\hline Photocatalysis & Sewage effluent & $15.10(\$ / L)$ for all the process & {$[47]$} \\
\hline Fenton reagent & $\begin{array}{c}\text { Phenol waste } \\
\text { water }\end{array}$ & 14.28 (\$/1000 gallon) & {$[48]$} \\
\hline Photo-Fenton & $\begin{array}{c}\text { Tannery waste } \\
\text { water }\end{array}$ & $64.13\left(\mathrm{US} \$ \mathrm{~m}^{-3}\right)$ & {$[49]$} \\
\hline Photo-Fenton & Pesticides & $1.1-1.9 € \mathrm{~m}^{-3}$ & {$[50]$} \\
\hline
\end{tabular}


alkaline hydrolysate (lignin solution). Taguchi $\mathrm{L}_{9}$ experimental matrix proved that UV irradiation was the most significant factor with $\mathrm{F}$ value of 404.00 , which significantly removed $98.65 \% \mathrm{TP}$ and $95.73 \%$ of TOC reduction. The results have proved the efficiency of photochemical technology (AOP) in the treatment of residues generated during the alkali mediated delignification pretreatment of SB.

\section{Competing interests}

The authors declare that they have no competing interests.

\section{Authors' contributions}

ISO carried out the experimental work. ISO, AKC and MBS designed the study and were involved in all discussions, interpretation of data and writing the manuscript. SSS coordinated the overall study, analysis of results and finalizing the manuscript. All authors suggested modifications to the draft and approved the final manuscript.

\section{Acknowledgement}

We are grateful to the FAPESP for providing the financial support under the thematic project -2008/57926-4 and 2010/08066-2.

\section{Author details}

'Department of Biotechnology, Engineering School of Lorena, University of São Paulo, Estrada Municipal do Campinho, P.O. Box, Lorena/SP 116 12.602.810, Brazil. ${ }^{2}$ Department of Chemical Engineering, Engineering School of Lorena, University of São Paulo, Lorena 12.602.810, Brazil.

Received: 31 May 2013 Accepted: 3 September 2013

Published: 8 October 2013

\section{References}

1. Goldemberg J, Coelho S, Guardabassi P: The sustainability of ethanol production from sugarcane. Ener Pol 2008, 36:2086-2097.

2. Ojeda K, Ávila O, Suárez J, Kafarov V: Evaluation of technological alternatives for process integration of sugarcane bagasse for sustainable biofuels. Chem Eng Res Design 2011, 89:270-279.

3. Chandel AK, Chan EC, Rudravaram R, Narasu ML, Rao LV, Ravindra P: Economics and environmental impact of bioethanol production technologies: an appraisal. Biotechnol Mol Biol Rev 2007, 2:014-032.

4. Cardona CA, Sánchez ÓJ: Fuel ethanol production: process design trends and integration opportunities. Bioresour Technol 2010, 98:2415-2457.

5. Chandel AK, Silva SS, Carvalho W, Singh OV: Sugarcane bagasse and leaves: foreseeable biomass of biofuel and bio-products. J Chem Technol Biotechnol 2012, 87:11-20.

6. Rezende CA, Lima MA, Maziero P, Azevedo ER, Garcia W, Polikarpov I: Chemical and morphological characterization of sugarcane bagasse submitted to a delignification process for enhanced enzymatic digestibility. Biotechnol Biofuels 2011, 4:54

7. Giese EC, Pierozzi M, Dussan KJ, Chandel AK, Silva SS: Enzymatic saccharification of acid-alkali pretreated sugarcane bagasse using commercial enzyme preparations. J Chem Technol Biotechnol 2012, 88:1266-1272

8. Canilha L, Chandel AK, Milessi TSS, Antunes FAF, Freitas WLC, Felipe MGA, Silvio SS: Bioconversion of sugarcane biomass into ethanol: an overview about composition, pretreatment methods, detoxification of hydrolysates, enzymatic saccharification, and ethanol fermentation. J Biomed Biotechnol 2012, 1:15.

9. Mussatto SI, Dragone G, Guimarães PMR, Silva JPA, Carneiro LM, Roberto IC Vicente A, Domingues L, Teixeira JA: Technological trends, global market, and challenges of bio-ethanol production. Biotechnol Adv 2010, 28:817-830

10. Zhu JY, Pan XJ: Woody biomass pretreatment for cellulosic ethanol production: Technology and energy consumption evaluation. Bioresour Technol 2010, 101:4992-5002.

11. Wang L, Chen H: Increased fermentability of enzymatically hydrolyzed steam-exploded corn stover for butanol production by removal of fermentation inhibitors. Proc Biochem 2011, 46:604-607.

12. Canilha L, Santos VTO, Rocha GJM, Silva JBA, Giulietti M, Silva SS, Felipe MGA, Ferraz A, Milagres AMF, Carvalho W: A study on the pretreatment of a sugarcane bagasse sample with dilute sulfuric acid. $J$ Ind Microbiol Biotechnol 2011, 38:1467-1475.

13. Chandel AK, Silva SS, Singh OV: Detoxification of lignocellulose hydrolysates: Biochemical and metabolic engineering towards white biotechnology. Bio Ener Res 2013, 6:388-401.

14. Rodrigues GD, Silva LHM, Silva MCH: Alternativas verdes para o preparo de amostras e determinação de poluentes fenólicos em água. Química Nova 2010, 33:1370-1378.

15. Uğurlu M, Gürses A, Doğar Ç, Yalçın M: The removal of lignin and phenol from paper Mill effluents by electrocoagulation. J Environ Manag 2008, 87:420-428

16. Uğurlu $\mathrm{M}$, Karaoğlu $\mathrm{MH}: \mathrm{TiO}_{2}$ supported on sepiolite: preparation, structural and thermal characterization and catalytic behaviour in photocatalytic treatment of phenol and lignin from olive mill wastewater. Chem Eng J 2011, 166:859-867.

17. Cansado IPP, Mourão PAM, Falcão Al, Ribeiro Carrott MML, Carrott PJM: The influence of the activated carbon post-treatment on the phenolic compounds removal. Fuel Proc Technol 2012, 103:64-70.

18. Gonçalves MR, Costa JC, Marques IP, Alves MM: Strategies for lipids and phenolics degradation in the anaerobic treatment of olive mill wastewater. Water Res 2012, 46:1684-1692.

19. Amendola D, De Faveri DM, Egües I, Serrano L, Labidi J, Spigno G: Autohydrolysis and organosolv process for recovery of hemicelluloses, phenolic compounds and lignin from grape stalks. Bioresour Technol 2012, 107:267-274.

20. Babuponnusamia A, Muthukumar K: Advanced oxidation of phenol: A comparison between Fenton, electro-Fenton, sono-electro-Fenton and photo-electro-Fenton processes. Chem Eng J 2012, 183:1-9.

21. Oller I, Malato S, Sánchez-Pére JA: Combination of advanced oxidation processes and biological treatments for wastewater decontamination - a review. Sci Total Environ 2011, 409:4141-4166.

22. Fatta-Kassinos D, Vasquez Ml, Kümmerer K: Transformation products of pharmaceuticals in surface waters and wastewater formed during photolysis and advanced oxidation process - Degradation, elucidation of by products and assessment of their biological potency. Chemosphere 2011, 85:693-709.

23. Lamsal R, Walsh ME, Gagnon GA: Comparison of advanced oxidation processes for the removal of natural organic matter. Water Res 2011 45:3263-3269.

24. Wols BA, Hofman-Caris CHM: Review of photochemical reaction constants of organic micropollutants required for UV advanced oxidation processes in water. Water Res 2012, 46:2815-2827.

25. Sharma VK, Triantis TM, Antoniou MG, He X, Pelaez M, Han C, Song W, O'Shea KE, de La Cruz AA, Kaloudis T, Hiskia A, Dionysiou DD: Destruction of microcystins by conventional and advanced oxidation processes: $\mathrm{A}$ review. Sep Purif Technol 2012, 91:3-17.

26. Tobaldi DM, Tucci A, Camera-Roda G, Baldi DG, Esposito L: Photocatalytic activity for exposed building materials. J European Ceramic Soc 2008 , 28:2645-2652

27. Michalska K, Miazek K, Krzystek L, Ledakowicz S: Influence of pretreatment with Fenton's reagent on biogas production and methane yield from lignocellulosic biomass. Bioresour Technol 2012, 119:72-78.

28. Cortez S, Teixeira P, Oliveira R, Mota M: Evaluation of Fenton and ozonebased advanced oxidation process as mature landfill leachate pretreatments. J Environ Manag 2011, 92:749-755.

29. Chu L, Wang J, Dong J, Liu H, Sun X: Treatment of coking wastewater by an advanced Fenton oxidation process using iron powder and hydrogen peroxide. Chemosphere 2012, 86:409-414

30. APHA, American Public Health Association: Standard Methods for Examination of Water and Wastewater. 21st edition. Washington, DC: (APHA, AWWA); 2005:2001-3710

31. Lucas MS, Peres JA, Amor C, Prieto-Rodríguez L, Maldonado MI, Malato S Tertiary treatment of pulp mill wastewater by solar photo-Fenton. J Hazard Mat 2012, 225-226:173-181.

32. Ma Y, Chang C, Chiang Y, Sung H, Chao AC: Photocatalytic degradation of lignin using $\mathrm{Pt} / \mathrm{TiO}_{2}$ as the catalyst. Chemosphere 2008, 71:998-1004.

33. Ninomiya K, Takamatsu H, Onishi A, Takahashi K, Shimizu N: SonocatalyticFenton reaction for enhanced $\mathrm{OH}$ radical generation and its application to lignin degradation. Ultrasonics Sonochem 2013, 20:1092-1097.

34. Makhotkina OA, Preis SV, Parkhomchuk EV: Water delignification by advanced oxidation processes: Homogeneous and heterogeneous 
Fenton and $\mathrm{H} 2 \mathrm{O} 2$ photo-assisted reactions. Appl Catal B: Environmental 2008, 84:821-826.

35. Pupo Nogueira RF, Trovó AG, Silva MRA, Villa RD: Fundamentos e aplicações ambientais dos processos Fenton e foto-Fenton. Química Nova 2007, 30:400-408.

36. Manenti DR, Gomes LFS, Borba FH, Módenes NA, Espinoza-Ouiñones FR, Palácio SM: Otimização do processo foto-Fenton utilizando irradiação artificial na degradação do efluente têxtil sintético. Engevista 2010, 12:22-32.

37. Hermosilla D, Merayo N, Ordóñez R, Blanco A: Optimization of conventional Fenton and ultraviolet-assisted oxidation processes for the treatment of reverse osmosis retentate from a paper Mill. Waste Manag 2012, 32:1236-1243.

38. Samet $Y$, Hmani $E$, Abdelhédi R: Fenton and solar photo-Fenton processes for the removal of chlorpyrifos insecticide in wastewater. Water 2012, 38:537-542.

39. Bentivenga G, Bonini C, D'Auria M, De Bona A: Degradation of steamexploded lignin from beech by using Fenton's reagent. Biomass Bioener 2003, 24:233-238.

40. Salazar RFS, Peixoto ALC, Izário Filho HJ: Avaliação da metodologia 5220 D. Closed reflux, colorimetric method para determinação da demanda química de oxigênio (DQO) em efluentes lácteo. Analytica 2010, 44:55-61.

41. Companhia de Tecnologia de Saneamento Ambiental: Variáveis de Qualidade das Águas; 2013. Disponível em: [http://www.cetesb.sp.gov.br/ Agua/rios/variaveis.asp\#dbo] Accessed on April, 2013.

42. CONAMA - Conselho Nacional do Meio Ambiente: CONAMA - Conselho Nacional do Meio Ambiente. [http://www.mma.gov.br/conama] Accessed on April, 2013.

43. Autin O, Romelot C, Rust L, Hart J, Jarvis P, MacAdam J, Parsons SA, Jefferson B: Evaluation of a UV-light emitting diodes unit for the removal of micropollutants in water for low energy advanced oxidation processes. Chemosphere 2013, 92:745-751.

44. Azbar N, Yonar T, Kestioglu K: Comparison of various advanced oxidation processes and chemical treatment methods for COD and color removal from a polyester and acetate fiber dyeing effluent. Chemosphere 2004, 55:35-43.

45. Canizares P, Paz R, Sáez C, Rodrigo MA: Costs of the electrochemical oxidation of wastewaters: A comparison with ozonation and Fenton oxidation processes. J Environ Manag 2009, 90:410-420.

46. Chen YC, Smirniotis P: Enhancement of photocatalytic degradation of phenol and chloro-phenols by ultrasound. Ind Eng Chem Res 2002, 41:5958-5965.

47. Chong MN, Sharma AK, Burn S, Saint CP: Feasibility study on the application of advanced oxidation technologies for decentralized wastewater treatment. J Cleaner Prod 2012, 35:230-238.

48. Mahamuni NN, Adewuyi YG: Advanced oxidation processes (AOPs) involving ultrasound for waste water treatment: A review with emphasis on cost estimation. Ultrason Sonochem 2010, 17:990-1003.

49. Módenes AN, Espinoza-Quiñones FR, Borba FH, Manenti DR: Performance evaluation of an integrated photo-Fenton - Electrocoagulation process applied to pollutant removal from tannery effluent in batch system. Chem Eng J 2021, 197:1-9.

50. Pérez JAS, Sánchez IMR, Carra I, Reina AC, López JLC, Malato S: Economic evaluation of a combined photo-Fenton/MBR process using pesticides as model pollutant. Factors affecting costs. J Haz Mat 2013, 244-245:195-203.

doi:10.1186/2043-7129-1-20

Cite this article as: Oliveira et al:: Environmental assessment of residues generated after consecutive acid-base pretreatment

of sugarcane bagasse by advanced

oxidative process. Sustainable Chemical Processes 2013 1:20.

\section{Publish with ChemistryCentral and every scientist can read your work free of charge \\ "Open access provides opportunities to our colleagues in other parts of the globe, by allowing anyone to view the content free of charge." \\ W. Jeffery Hurst, The Hershey Company. \\ - available free of charge to the entire scientific community \\ - peer reviewed and published immediately upon acceptance \\ - cited in PubMed and archived on PubMed Central \\ - yours - you keep the copyright \\ Submit your manuscript here: \\ http://www.chemistrycentral.com/manuscript/<smiles>c1ccccc1</smiles> 